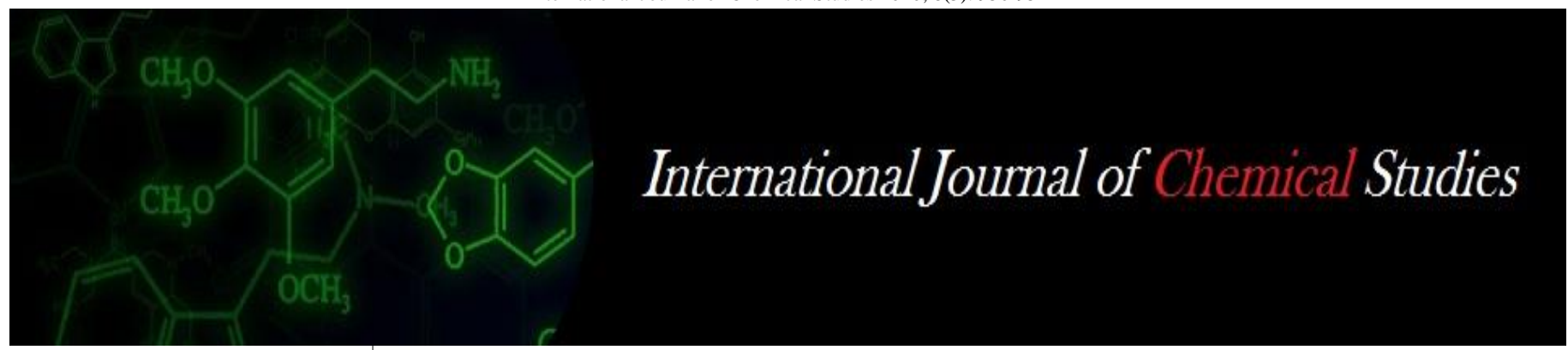

P-ISSN: 2349-8528

E-ISSN: 2321-4902

www.chemijournal.com

IJCS 2020; 8(3): 950-954

(C) 2020 IJCS

Received: 16-03-2020

Accepted: 18-04-2020

Ritesh Kumar Mishra

M. Tech. (Agricultural

Processing and Food

Engineering), IGKVV,

Raipur, Chhattisgarh, India

Dr. S Patel

Head of Department

(Agricultural Processing and

Food Engineering), IGKVV,

Raipur, Chhattisgarh, India

Corresponding Author: Ritesh Kumar Mishra M. Tech. (Agricultural Processing and Food Engineering), IGKVV, Raipur, Chhattisgarh, India

\section{Osmo-solar drying of bottle gourd (Legeneria Siceraria)}

\author{
Ritesh Kumar Mishra and Dr. S Patel
}

DOI: https://doi.org/10.22271/chemi.2020.v8.i31.9322

\begin{abstract}
The bottle gourd is a common vegetable in India subcontinental. Osmotic dehydration increases the storage ability of fruits and vegetables making them available throughout the year. Dehydrated products also play a great role in processed foods of all kinds and the way to achieve high quality dehydrated products are desired. The combination of osmosis with solar drying has been put forward, mainly for tropical fruit. A 24-hour cycle has been suggested combining osmodehydration, performed during the night, solar drying during the day. The well washed bottle gourd fruits were then peeled off with help of stainless-steel hand peeler. Pieces of bottle gourd cubes $(1 \mathrm{cmx} 1 \mathrm{cmx} 1 \mathrm{~cm})$ were then cut out using a ruler and knife. The salt solution with 5, 10, 15, 20, and 25\% (w/w) concentration were prepared. Bottle gourd cubes were immersed in the osmotic reagents with a fruit to osmotic solution mass ratio of 10:1, 20:1 and $30: 1$ soaking experiments were conducted at $40^{\circ} \mathrm{C}, 50^{\circ} \mathrm{C}$ and $60^{\circ} \mathrm{C}$ in a $500 \mathrm{mi}$ capacity water bath. The osmotic dehydration was done for a period of 1, 3, 5, 7 and $9 \mathrm{~h}$ and replicated thrice. The dependent variable studied was moisture content after dehydration. Moisture content of sample was determined by standard air oven method (Ranganna, 1995). The minimum moisture content was $46.9 \%$ (wb) for samples osmotically dehydrated at $60^{\circ} \mathrm{C}$ for $9 \mathrm{~h}$ at $30: 1$ fruit to osmotic solution at $25 \%$ concentration. The moisture content of bottle gourd cubes observed decreases with higher concentration, temperature and mass ratio. Solar drying characteristics of $9 \mathrm{~h}$ bottle gourd cubes at $60^{\circ} \mathrm{C}$ are determined by solar tray dryer. During the process of solar drying of $9 \mathrm{~h}$ bottle gourds cubes, the air temperature inside the cabinet varies 44 to $81^{\circ} \mathrm{C}$. and relative humidity inside the chamber was measures 34 to 58 percent. The minimum value of final moisture content of osmo-solar dried bottle gourd cubes was $8.3 \%$ at $60^{\circ} \mathrm{C}$ for sample of 10:1 mass ratio and maximum value of final moisture content was $24.4 \%$ of at $60^{\circ} \mathrm{C}$ for $30: 1$ sample.
\end{abstract}

Keywords: Legeneria Siceraria, osmotic dehydration, osmo-solar drying

\section{Introduction}

In India cultivated area of bottle gourd is 149000 ha with a production of 2458000 metric ton in 2015-16 (Horticultural statistics at a glance 2017) ${ }^{[9]}$. Its centre of origin has been located as the coastal area of Malabar (North Kerala and humid Forest of Deharadun). The fossil records indicate its culture in India even before 2000 BC. It is yellowish green, having the shape of bottle. It has white pulp, with white seeds embedded in spongy flesh. They were fairly reach in $\mathrm{Ca}, \mathrm{Fe}$ and $\mathrm{P}$ (Herwig, 2004) ${ }^{[7]}$. The nutritional value of the kernels was equal or better the that of cashew nut and almond kernels. Bottle gourd mostly cultivated Bihar, Uttar Pradesh, Haryana, Madhya Pradesh, Chhattisgarh. In Chhattisgarh bottle gourd cultivated in 12890 ha with production of 235890 MT in year 2015-16 (Horticultural statistics at a glance 2017) ${ }^{[9]}$. Osmotic dehydration brings about substantial reduction in weight and volume, minimizing packing, storage and transportation costs and enables storability of the product under ambient temperatures, Dehydration increases the storage ability of fruits and vegetables making them available throughout the year. The effects of osmotic dehydration as pre-treatment are mainly related to the improvement of some nutritional, organoleptic and functional properties of the product. As osmotic dehydration is effective at ambient temperature, heat damage to colour and flavor is minimized.

Mechanical drying of agricultural products is an energy consuming operation in the post harvesting technology. Greater emphasis is given to using solar energy sources in this process due to the high prices and shortages of fossil fuels. For these purposes, a solar air heater. This system can be used for drying various agricultural products like fruits and vegetables. 
The long period of sunshine and the use of solar power for drying seems to be the best solution. This method also maintains the best appearance of the fruits and vegetables. The combination of osmosis with solar drying has been put forward, mainly for tropical fruit. A 24-hour cycle has been suggested combining osmodehydration, performed during the night, solar drying during the day. Two-three-fold increase in the throughput of typical solar dryer is feasible, while enhancing the nutritional and organoleptic quality of the fruits.

Keeping this in the mind the present study has been conducted with the following objectives:

1. To study the moisture content characteristics of osmotic dehydrated bottle gourd cubes.

2. To study the solar drying characteristics of $9 \mathrm{~h}$ osmotically dehydrated samples of bottle gourd cubes at $60^{\circ} \mathrm{C}$.

\section{Materials and methods}

The experiment work was carried out in the Department of Agricultural Processing and Food Engineering, Indira Gandhi Agricultural University, Raipur (C.G.).

\subsection{Experimental plan}

To meet the proposed research objectives, research outlines in fig. 2.1 was followed in our experimental drying process.

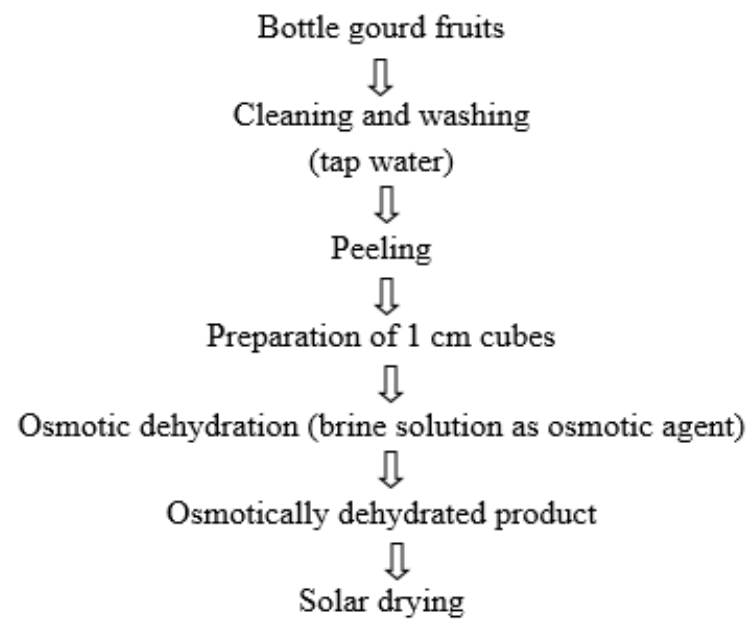

Fig 2.1: Process Flow-chart for the experiment

\subsection{Experimental set up for preliminary osmotic dehydration experiments}

Preliminary soaking experiments were conducted at 40, 50 and $60^{\circ} \mathrm{C}$. The experimental set up consisted of glass beakers of $500 \mathrm{ml}$ capacity, a water bath of heating capacity $110^{\circ} \mathrm{C}$ having temperature control arrangement $\left( \pm 2^{\circ} \mathrm{C}\right)$ and mercury in glass thermometer $\left(10\right.$ to $\left.200^{\circ} \mathrm{C}\right)$.

\subsection{Experimental Procedure}

Osmotic dehydration was carried out with commercially available table salt $(98 \%$ of minimum purity in sodium chloride) as osmotic agent. Five concentration levels of salt solution were used in this study to compare the effect of concentration of osmotic agent on osmotic dehydration. The salt solution with $5,10,15,20$, and $25 \%$ (w/w) concentration were prepared and bottle gourd cubes were immersed in the osmotic reagents with a fruit to osmotic solution mass ratio of 10;1, 20:1 and 30:1. The temperature of osmotic solution were 40,50 and $60^{\circ} \mathrm{C}$. The osmotic dehydration done for a period of $1,3,5,7$ and $9 \mathrm{~h}$ and repeated thrice. Afterwards samples were rinsed and wiped with tissues.

\subsection{Variables and their ranges}

The independent variables are type of osmotic solution salt, initial moisture content, soaking temperature and soaking time, mass ratio and concentration of osmotic agent.

- Type of Osmotic solution: Common salt (98\% of min. purity in $\mathrm{Nacl}$ )

- Concentration of Osmotic agent: 5, 10, 15, 20, 25\%(w/w)

- Time of osmotic dehydration: 1, 3, 5, 7 and $9 \mathrm{~h}$

- Mass ratio (sample to osmotic solution): 1:10, 1:20 and $1: 30$.

- Temperature of osmotic solution: 40,50 and $60^{\circ} \mathrm{C}$.

The dependent variables studies were,

(a) Moisture content after dehydration

\subsection{Measurement of dependent variables 2.5.1 Moisture content determination}

Moisture content of the sample was determined by standard air oven method (Ranganna 1995) ${ }^{[13]}$. Test sample of $100 \mathrm{~g}$ was kept for $24 \mathrm{~h}$ in a hot air electric oven maintained at $105^{\circ} \mathrm{C}$. After $24 \mathrm{~h}$, sample was drawn from the oven and placed in a desiccator for cooling. After cooling the weight of the sample was taken precisely. The loss was determined and moisture content was calculated using the following expression:

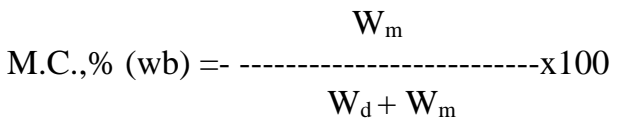

Where,

M.C. $=$ Moisture content, $\%$

$\mathrm{W}_{\mathrm{m}}=$ Weight of moisture,

$\mathrm{W}_{\mathrm{d}}=$ Weight of dry matter.

\subsection{Solar drying of bottle gourd cubes}

In the present study, an attempt was made to analyses the drying characteristics of the bottle gourd cubes using solar tray dryer. A multi rack solar tray dryer was fabricated at faculty of Agricultural Engineering, IGAU Raipur (C.G.) used for drying of bottle gourd cubes. it consisted of a transparent glass to transmit the solar radiations and three trays for loading the produce. The cabinet of the dryer is made up of GI sheet with thermocol insulation fitted on the frame of iron angle. The front portion fitted with glass is tilted at an angle of $45^{\circ} \mathrm{C}$ to facilitate maximum exposure to the solar radiation. The solar drying behavior of any biological material varies with relative humidity $(\mathrm{RH})$ of ambient air inside the dryer cabinet, ambient air temperature and inside temperature of the dryer, time of exposure to the sun light, size and shape of the material, internal structure of biological material and treatment of sample prior the drying.

The solar drying characteristics of bottle gourd cubes were evaluated under the following parameters.

a. Inside temperature of dryer,

b. Relative humidity (RH)

c. Weight of sample at fixed intervals.

Moisture removal of bottle gourd cubes were recorded with the help of precise digital electronic balance with least count of $0.1 \mathrm{~g}$. observation of temperature, $\mathrm{RH}$ and weight of sample cubes were recorded on observation sheet. 


\section{Results and Discussion}

\subsection{Osmotic dehydration experiment}

Bottle gourd cubes of $1 \mathrm{~cm}$ size were subjected to osmatic dehydration using commercial salt for osmatic solution of different concentrations. The range of independent variables were finalized on the basis of earlier work (Sereno et al., 2004) ${ }^{[14]}$ and preliminary trials conducted. The ranges were temperature 40,50 and $60^{\circ} \mathrm{C}$, osmotic dehydration time 1,3 , 5,7 and $9 \mathrm{~h}$, mass ratio of osmatic solution to the bottle gourd cubes (fruit cube): 30:1, 20:1 and 10:1 and concentration of osmotic solution 5, 10, 15, 20 and $25 \%$.

\subsubsection{Moisture studies}

The moisture content of bottle gourd cubes was calculated during osmotic dehydration experiment each after $1,3,5,7$ and $9 \mathrm{~h}$ respectively. The values of moisture content are presented in Table 3.1 through 3.3.

Table 3.1: Mean values of moisture content $(\%, w b)$ of osmotically dehydrated bottle gourd at 40 Degree Celsius

\begin{tabular}{|c|c|c|c|c|c|c|c|c|c|c|c|c|c|c|c|c|c|c|c|c|}
\hline \multirow{4}{*}{$\mathrm{T}$} & \multicolumn{20}{|c|}{ Mass ratio } \\
\hline & \multicolumn{5}{|c|}{$10: 1$} & \multicolumn{5}{|c|}{$20: 1$} & \multicolumn{5}{|c|}{$30: 1$} & \multicolumn{5}{|c|}{ Mean } \\
\hline & \multicolumn{5}{|c|}{ Concentration (\%) } & \multicolumn{5}{|c|}{ Concentration (\%) } & \multicolumn{5}{|c|}{ Concentration (\%) } & \multicolumn{5}{|c|}{ Concentration (\%) } \\
\hline & 5 & 10 & 15 & 20 & 25 & 5 & 10 & 15 & 20 & 25 & 5 & 10 & 15 & 20 & 25 & 5 & 10 & 15 & 20 & 25 \\
\hline 0 & 96.3 & 96.3 & 96.3 & 96.3 & 96.3 & 96.3 & 96.3 & 96.3 & 96.3 & 96.3 & 96.3 & 96.3 & 96.3 & 96.3 & 96.3 & 96.3 & 96.3 & 96.3 & 96.3 & 96.3 \\
\hline 1 & 93.4 & 91.6 & 85.4 & 80.1 & 75.2 & 93.4 & 90.2 & 85.7 & 80.2 & 74.8 & 93.0 & 84.1 & 82.3 & 73.4 & 67.4 & 93.3 & 88.6 & 84.5 & 77.9 & 72.5 \\
\hline 3 & 92.2 & 88.3 & 82.8 & 71.3 & \begin{tabular}{|l|l}
62.8 \\
\end{tabular} & 91.4 & 85.9 & 82.4 & 71.9 & 62.8 & 91.9 & 82.8 & 89.2 & 72.1 & 62.6 & 91.8 & 85.7 & 84.8 & 71.8 & 62.7 \\
\hline 5 & 91.6 & 85.3 & 79.1 & 75.3 & \begin{tabular}{|l|}
56.4 \\
\end{tabular} & 90.8 & 84.2 & 77.5 & 75.0 & 58.2 & 91.4 & 82.5 & 78.9 & 67.2 & 57.3 & 91.3 & 84.0 & 78.5 & 72.5 & 57.3 \\
\hline 7 & 90.6 & 82.3 & 75.2 & 59.6 & \begin{tabular}{|l|l}
53.2 \\
\end{tabular} & 90.1 & 82.2 & 73.8 & 65.1 & 51.7 & 90.8 & 82.2 & 78.1 & 64.8 & 52.6 & 90.5 & 82.2 & 75.7 & 63.2 & 52.5 \\
\hline 9 & 89.6 & 80.7 & 73.2 & 56.2 & 53.7 & 88.8 & 80.1 & 72.9 & 62.5 & 52.8 & 84.6 & 80.3 & 77.8 & 65.2 & 51.7 & 87.7 & 80.4 & 74.6 & 61.3 & 52.7 \\
\hline $\mathrm{M}$ & 92.3 & 87.4 & 82.0 & 73.1 & \begin{tabular}{|l|l}
66.3 \\
\end{tabular} & 91.8 & 86.5 & 81.4 & 75.2 & 66.1 & 91.3 & 84.7 & 83.8 & 73.2 & 64.7 & & & & & \\
\hline
\end{tabular}

Table 3.2: Mean values of moisture content $(\%, w b)$ of osmotically dehydrated bottle gourd at 50 Degree Celsius

\begin{tabular}{|c|c|c|c|c|c|c|c|c|c|c|c|c|c|c|c|c|c|c|c|c|}
\hline \multirow{4}{*}{$\mathbf{T}$} & \multicolumn{20}{|c|}{ Mass ratio } \\
\hline & \multicolumn{5}{|c|}{ 10:1 } & \multicolumn{5}{|c|}{ 20:1 } & \multicolumn{5}{|c|}{ 30:1 } & \multicolumn{5}{|c|}{ Mean } \\
\hline & \multicolumn{5}{|c|}{ Concentration (\%) } & \multicolumn{5}{|c|}{ Concentration (\%) } & \multicolumn{5}{|c|}{ Concentration (\%) } & \multicolumn{5}{|c|}{ Concentration (\%) } \\
\hline & 5 & 10 & 15 & 20 & 25 & 5 & 10 & 15 & 20 & 25 & 5 & 10 & 15 & 20 & 25 & 5 & 10 & 15 & 20 & 25 \\
\hline 0 & 96.0 & 96.0 & 96.0 & 96.0 & 96.0 & 96.0 & 96.0 & 96.0 & 96.0 & 96.0 & 96.0 & 96.0 & 96.0 & 96.0 & 96.0 & 96.0 & 96.0 & 96.0 & 96.0 & 96.0 \\
\hline 1 & 92.2 & 88.8 & 85.1 & 80.5 & 75.6 & 92.6 & 88.1 & 85.3 & 79.2 & 75.5 & 92.1 & 83.7 & 81.6 & 73.8 & 65.9 & 92.3 & 86.9 & 84.0 & 77.8 & 72.3 \\
\hline 3 & 90.6 & 86.6 & 81.8 & 72.2 & 62.1 & 91.6 & 86.3 & 81.9 & 72.0 & 61.8 & 91.3 & 81.2 & 78.4 & 71.2 & 60.5 & 91.2 & 84.7 & 80.7 & 71.8 & 61.5 \\
\hline 5 & 90.6 & 84.5 & 77.3 & 66.3 & 58.3 & 90.3 & 84.3 & 78.2 & 63.3 & 67.4 & 92.3 & 81.5 & 75.2 & 78.2 & 65.6 & 91.1 & 83.4 & 76.9 & 69.3 & 63.8 \\
\hline 7 & 89.6 & 82.2 & 74.3 & 59.2 & 51.9 & 88.6 & 82.4 & 73.8 & 59.1 & 51.7 & 88.0 & 81.7 & 72.8 & 65.1 & 51.2 & 88.7 & 82.1 & 73.6 & 61.1 & 51.6 \\
\hline 9 & 88.6 & 80.5 & 72.1 & 55.8 & 52.3 & 89.3 & 80.4 & 73.1 & 56.5 & 51.2 & 84.3 & 80.2 & 72.3 & 60.6 & 49.3 & 87.4 & 80.4 & 72.5 & 57.6 & 50.9 \\
\hline $\bar{M}$ & 91.3 & 86.4 & 81.1 & 71.7 & 66.0 & 91.4 & 86.3 & 81.4 & 71.0 & 67.3 & 90.7 & 84.1 & 79.4 & 74.2 & 64.8 & & & & & \\
\hline
\end{tabular}

Table 3.3: Mean values of moisture content $(\%, w b)$ of osmotically dehydrated bottle gourd at 60 Degree Celsius

\begin{tabular}{|c|c|c|c|c|c|c|c|c|c|c|c|c|c|c|c|c|c|c|c|c|}
\hline \multirow{4}{*}{$\mathbf{T}$} & \multicolumn{20}{|c|}{ Mass ratio } \\
\hline & \multicolumn{5}{|c|}{ 10:1 } & \multirow{2}{*}{\multicolumn{5}{|c|}{\begin{tabular}{c|}
$20: 1$ \\
Concentration (\%)
\end{tabular}}} & \multicolumn{5}{|c|}{ 30:1 } & \multicolumn{5}{|c|}{ Mean } \\
\hline & \multicolumn{5}{|c|}{ Concentration (\%) } & & & & & & \multicolumn{5}{|c|}{ Concentration (\%) } & \multicolumn{5}{|c|}{ Concentration (\%) } \\
\hline & 5 & 10 & 15 & 20 & 25 & 5 & 10 & 15 & 20 & 25 & 5 & 10 & 15 & 20 & 25 & 5 & 10 & 15 & 20 & 25 \\
\hline 0 & 95.6 & 95.6 & 95.6 & 95.6 & 95.6 & 95.6 & 95.6 & 95.6 & 95.6 & 95.6 & 95.6 & 95.6 & 95.6 & 95.6 & 95.6 & 95.6 & 95.6 & 95.6 & 95.6 & 95.6 \\
\hline 1 & 92.2 & 88.5 & 85.6 & 82.1 & 68.3 & 91.3 & 87.5 & 84.8 & 76.8 & 67.7 & 89.0 & 82.3 & 70.8 & 70.4 & 68.9 & 90.8 & 86.1 & 80.4 & 76.4 & 68.3 \\
\hline 3 & 91.4 & 87.3 & 81.9 & 71.2 & 54.9 & 90.1 & 86.4 & 81.2 & 71.9 & 60.9 & 89.2 & 80.0 & 76.3 & 69.0 & 60.9 & 90.2 & 84.6 & 79.8 & 70.7 & 58.9 \\
\hline 5 & 89.3 & 84.2 & 78.3 & 66.3 & 53.8 & 88.6 & 84.2 & 76.6 & 74.4 & 56.4 & 88.5 & 80.4 & 74.4 & 63.7 & 55.2 & 88.8 & 82.9 & 76.4 & 68.1 & 55.1 \\
\hline 7 & 87.5 & 82.2 & 73.9 & 56.8 & 51.7 & 86.5 & 81.9 & 74.2 & 59.1 & 50.8 & 88.1 & 80.2 & 72.3 & 59.3 & 53.2 & 87.4 & 81.4 & 73.5 & 58.4 & 51.9 \\
\hline 9 & 89.1 & 81.3 & 71.9 & 54.6 & 50.1 & 86.8 & 79.8 & 72.2 & 55.0 & 49.9 & 82.1 & 78.2 & 69.1 & 51.4 & 46.9 & 86.0 & 79.8 & 71.1 & 53.7 & 49.0 \\
\hline$M$ & 90.9 & 86.5 & 81.2 & 71.1 & 62.4 & 89.8 & 85.9 & 80.8 & 72.1 & 63.6 & 88.8 & 82.8 & 76.4 & 68.2 & 63.5 & & & & & \\
\hline
\end{tabular}

As can be observed that as the concentration of osmotic solution increased the loss of moisture increased. The value of moisture content at $60^{\circ} \mathrm{C}$ temperature were $89.1 \%, 86.8 \%$, $82.1 \%(\mathrm{wb})$ at $5 \%$ concentration; $81.3 \%, 79.8 \%, 78.2 \%(\mathrm{wb})$ at $10 \%$ concentration; $71.9 \%, 72.2 \%, 69.1 \%(\mathrm{wb})$ at $15 \%$ concentration; $54.6 \%, 55.0 \%, 51.4 \% \%(\mathrm{wb})$ at $20 \%$ concentration; $50.1 \%, 49.9 \%, 46.9 \% \%(\mathrm{wb})$ at $25 \%$ concentration of the mass ratio of $10: 1,20: 1$ and $30: 1$ respectively after a period of $9 \mathrm{~h}$ of dehydration. The rate of loss of moisture content also increased beyond $10 \%$ concentration of osmotic solution. This was due to the fact with the increase in salt concentration the osmotic pressure difference increases which cause in the driving force.

The effect of dehydration time on loss of moisture indicates that the as the time increases the loss of moisture increases. This was true for all the combination of mass ratio and temperature set. The values of moisture content at $25 \%$ concentration of osmotic solution were $68.3 \%, 67.7 \%, 68.9 \%$ after $1 \mathrm{~h}$ dehydration; $54.9 \%, 60.9 \%, 60.9 \%$ (wb) after $3 \mathrm{~h}$; $53.8 \%, 56.4 \%$, and $55.2 \%(\mathrm{wb})$ after $5 \mathrm{~h} ; 51.7 \%, 50.8 \%$ and $53.2 \%(\mathrm{wb})$ after $7 \mathrm{~h} ; 50.1 \%, 49.9 \%$ and $46.9 \%$ (wb) after $9 \mathrm{~h}$ of dehydration for the mass ratio of 10:1, 20:1 and 30:1 respectively for the osmotic temperature of $60^{\circ} \mathrm{C}$. Further, at the initial stage of drying the rate of moisture migration (removal) was higher as depicted from the figures which gradually reduced as the drying time progressed. The highest removal of moisture was in the initial stage of dehydration i.e., upto $1 \mathrm{~h}$ of dehydration as compared to final stage of dehydration i.e., from 3 to $9 \mathrm{~h}$ in the case of $60^{\circ} \mathrm{C}$ and similar trend were followed for $50^{\circ} \mathrm{C}$ and $40^{\circ} \mathrm{C}$. Similarly, while comparing different osmotic temperatures for the same set of mass ratio $(30: 1)$ the value of moisture content at $25 \%$ concentration of osmotic solution were $46.9 \%$ (wb) $60^{\circ} \mathrm{C}$; $49.3 \%$ at $50^{\circ} \mathrm{C} ; 51.7 \%(\mathrm{wb})$ at $40^{\circ} \mathrm{C}$ which were dehydrated 
for $9 \mathrm{~h}$. This suggested that at same concentration of osmotic solution, higher temperature is responsible for higher removal of moisture from the sample.

\subsection{Solar drying characteristics of bottle gourd cubes}

During the process of drying of $(9 \mathrm{~h})$ bottle gourd cubes, the air temperature on black polythene sheet was observed to vary from 39 to $55^{\circ} \mathrm{C}$, and inside the cabinet it varies from 44 to $81^{\circ} \mathrm{C}$, the relative humidity of the ambient air and inside the chamber was measured to be 36 to $61 \%$, and 34 to $58 \%$, respectively. Maximum inside temperature of dryer samples of mass ratio of 10:1, 20:1 and 30:1 of $9 \mathrm{~h}$ was measured $81{ }^{\circ} \mathrm{C}$ at $2: 30 \mathrm{pm}, 81^{\circ} \mathrm{C}$ at $3: 00 \mathrm{pm}$ and, $81^{\circ} \mathrm{C}$ respectively. And the maximum RH for bottle gourd samples of mass ratio 10:1, $20: 1$ and $30: 1$ of $9 \mathrm{~h}$, inside the chamber was measured $62 \%$, $61 \%$ and $61 \%$, respectively. The RH increased initially for $2 \mathrm{~h}$ of drying and after that it reduces with higher drying period. The drying behavior of bottle gourd cubes of different mass ratio $(10: 1,20: 1$ and 30:1) and different concentration (5\%, $10 \%, 15 \%, 20 \%$ and $25 \%$ ) at temperature of $60^{\circ} \mathrm{C}$ for solar tray drying is presented in Fig. 3.1 as a plot of moisture content versus drying time.
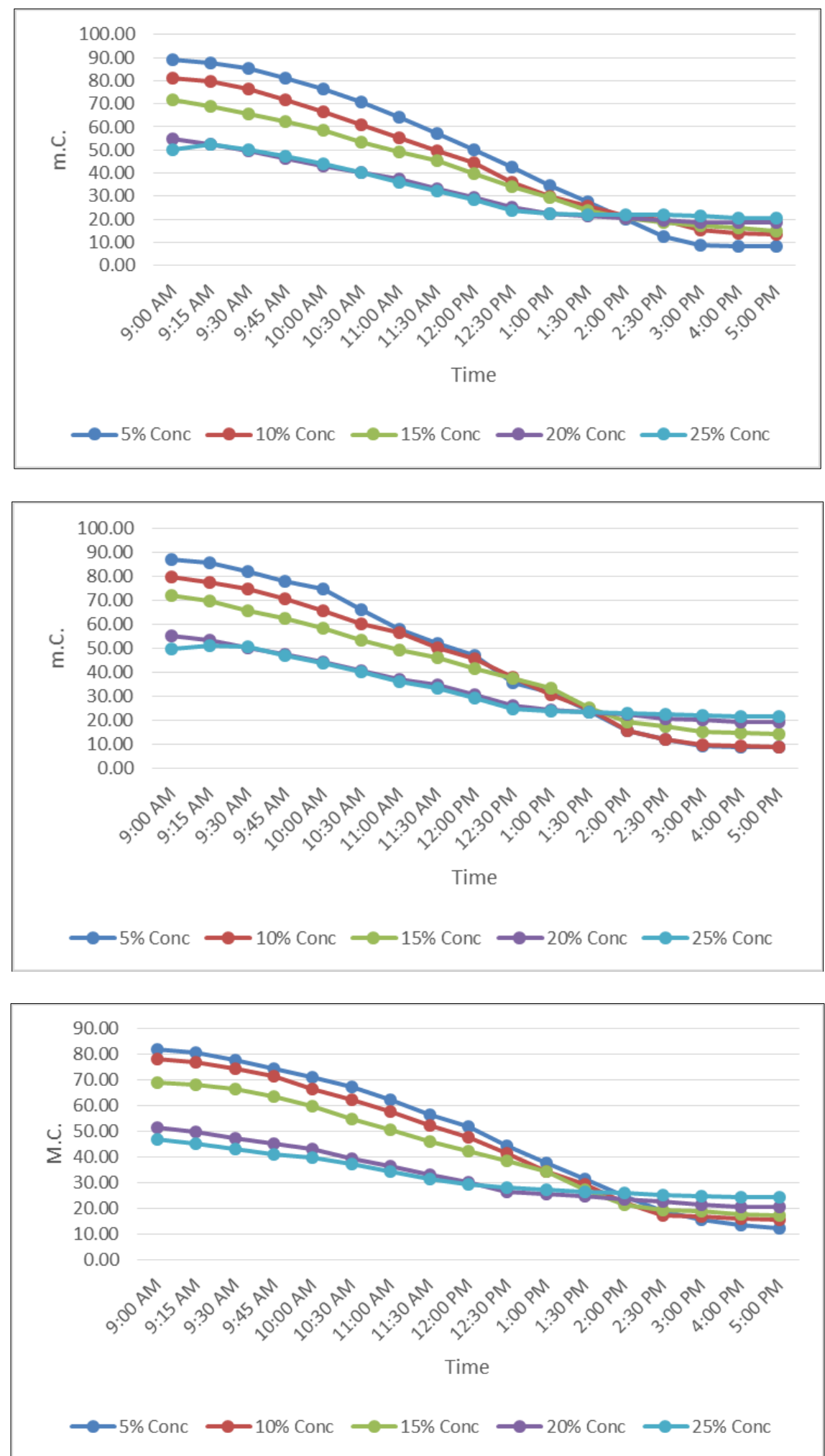

Fig 3.1: Solar drying of osmotically dehydrated samples of bottle gourd at $60^{\circ} \mathrm{C}$. For mass ratio of $10: 1$, (b) for the mass ratio of $20: 1$ and (c) for mass ratio of 30:1. 
The ambient temperature was measured at an interval of 15 min. for first 2 hours, at $30 \mathrm{~min}$. for next 2 hours and at hourly for rest of drying period for all treatment. The effect of drying time on moisture removal of sample were higher at initial period of 2-3 $\mathrm{h}$ in all treatment and it lowers for high drying time. Not much variation was observed in the drying behavior of bottle gourd cubes however the final moisture content of the samples was differed slightly. The final moisture content of $10: 1,9 \mathrm{~h}$ samples were recorded $8.3 \%, 13.4 \%, 15.1 \%$, $18.7 \%$ and $20.6 \%$ for $20: 1,9 \mathrm{~h}$ samples were recorded to be $8.7 \%, 8.6 \%, 14.2 \%, 19.3 \%$ and $21.5 \%$ and for $30: 1,9 \mathrm{~h}$ samples $12.4 \%, 15.6 \%, 17.3 \%, 20.4 \%$ and $24.4 \%$ recorded. The minimum value of final moisture content of osmo-solar dried bottle gourd cubes was $8.3 \%$ at $60^{\circ} \mathrm{C}$ for sample of $10: 1$ mass ratio and maximum value of final moisture content was $24.4 \%$ at $60^{\circ} \mathrm{C}$ for $30: 1$ sample.

\section{Conclusion}

Based on the result reported in previous chapter, following conclusions were drawn

1. The maximum moisture content observed was $93.4 \%$ (wb) for samples osmotically dehydrated at $40^{\circ} \mathrm{C}$ for $1 \mathrm{~h}$ at 10:1 fruit to osmotic solution at $5 \%$ concentration. The minimum moisture content was $46.9 \%(\mathrm{wb})$ for samples osmotically dehydrated at $60^{\circ} \mathrm{C}$ for $9 \mathrm{~h}$ at $30: 1$ fruit to osmotic solution at $25 \%$ concentration.

2. During the process of solar drying of $9 \mathrm{~h}$ bottle gourds cubes, the air temperature inside the cabinet varies 44 to $81^{\circ} \mathrm{C}$. and relative humidity inside the chamber was measures 34 to 58 percent.

3. The effect of drying time on moisture removal of sample were higher at initial period of 2-3 $\mathrm{h}$ and it lowers for high drying time. The $\mathrm{RH}$ increased initially for $2 \mathrm{~h}$ of drying and after that it reduces with higher drying period.

4. The minimum value of final moisture content of osmosolar dried bottle gourd cubes was $8.3 \%$ at $60^{\circ} \mathrm{C}$ for sample of 10:1 mass ratio and maximum value of final moisture content was $24.4 \%$ of at $60^{\circ} \mathrm{C}$ for $30: 1$ sample.

\section{References}

1. Arora Sadhna, Kumar Satish. Effect of osmo-solar dehydration of grapes on the quality of raisins. International Journal of Tropical Agriculture. 1999. 17(1/4):199-202.

2. Bawa AS, Gujral HS. Effect of osmotic agents on the drying behaviour and product quality in raisin processing. Journal of Scientific and Induustrial Research. 2000; 59(1):63-66.

3. Bhgyalaxmi Hema P. Studies of osmotic dehydration of bottle gourd (Lagenaria siceraria). Submitted to Faculty of Agricultural Engineering, IGKVV, Raipur, (C.G.), 2006.

4. Brandao MC, Maia GA, Lima DP, SaParente EJ, De Campello CC, Nassu RT et al. Physiochemical, microbiological and sensorial analysis of fruits of mango submitted to osmotic-solar dehydration. Revista Brasileira de Fruticultura. 2003; 25(1): 38-41.

5. El shiatry MA, Muller J, Muhlbauer W. Drying fruits and vegetables with solar energy in Egypt. Agricultural Mechanization in Asia, Africa and Latin America. 1991; 22(4): 61-64.

6. Gowda SJ, Talukdar KC, Ramaiah H. Studies on drying characteristics of tomato seeds (Pusa Ruby) (Lycopersicon esculentum Mill.) Progressive Horticulture. 1992; 21(3-4):296-299.
7. Herwig T. Notes on Lagenaria and Cucurbita: Review and new contributions-Phyton (Horn, Austria). 2004; 44(2):245-308.

8. Hauser M, El Bouamri M, Muhlbauer W. Solar drying of apricots. Arboriculture Fruitiere. 1993; (465):33-40.

9. Horticultural Statistics at a Glance. Page No. 16 and 195. Hrticulture Statistcs Division, Ministry of Agriculture and Farmer Welfare, Government of India, 2017.

10. Nehru C, Kumar VJF, Maheshwari CU, Gothandapani L. Solar drying characteristics of oyster mushroom. Mushroom Research. 1995; 4(1):27-30.

11. Nieto AB, Salvatori DM, Castro MA, Alzamora SM. Structural changes in apple tissue during glucose and sucrose osmotic dehydration. J Fd. Engg. 2004; 41(2):2431.

12. Pande VK, Sonune AV, Philip SK. Solar drying of coriander and methi leaves. Journal of Food Science and Technology Mysore. 2000; 37(6):592-595.

13. Ranganna $\mathrm{S}$. Hnadbook of analysis andquality control for fruit vegetables product, Tata Mcgraw Hill Publication Company Limited, New Delhi, 1995, 127-130.

14. Sereno AM, Mayor L, Moreira R. Dehydration of pumpkin using salt as osmotic agent: Evaluation of water and salt coefficients of diffusion. In: Drying Proceedings of the $14^{\text {th }}$ International Drying Symposium, Sao Paulo, Brazil, 2004, 22-258, 2157-2164.

15. Selvaraj JA. Studies on sun drying of brinjal seed. South Indian Horticulture. 1988; 36(5):273-276.

16. Souti M, Sahari MA, Jomeh ZE. Improving the dehydration of dried peach by applying osmotic method. Iranian Journal of Agricultural Sciences. 2003; 34(2):283-291. 